Click www.researchjournal.co.in/online/subdetail.html to purchase.

International Journal of Commerce and Business Management

\title{
Net worth statement, income statement and performance of residential farm business in Maharashtra
}

\author{
D.B. PAWAR AND P. U. KAUTHEKAR
}

Received : 12.01.2017; Revised : 05.03.2017; Accepted : 19.03.2017

\begin{abstract}
The study was carried out during the year 2013-14 in Parbhani district of Maharashtra. About 48 residential farms were randomly selected from sixteen villages of two tehsils of Parbhani district of Maharashtra. Data were collected by personal interview method by using pretested schedule. The results revealed that, current asset was Rs. 541522.89 while intermediate asset was Rs. 109321.64 and long term asset was Rs.2071565.70. Hence, total asset was Rs. 2722410.23. The amount of total liability was Rs.241922.58 in which long term libility was Rs. 125533.53 followed by intermediate liability Rs. 29769.05 and current liability was Rs. 86620. Hence, net worth or equity was Rs.2480487.65. In income statement, gross cash income was Rs. 474092.89 and amount of total receipt was Rs. 630592.89. Total expense was Rs. 285890.17. Amount of net farm income was Rs. 344702.72.In regards to performance of residential farm business, current ratio was found to be 6.25 . The intermediate ratio was found to be 5.59. The net capital ratio was 11.25.Current liability ratio was 0.03 which indicated negligible amount of current liability as compared to owner's equity. Debt-equity ratio was 0.09 and Equity value ratio was 0.91 on residential farm business. Operating ratio was found to be 0.42 . Fixed ratio was 0.17 . and gross net profit ratio was found to be 0.60 .
\end{abstract}

KEY WORDS : Net worth statement, Income statement, Residential farm

How to cite this paper : Pawar, D.B. and Kauthekar, P.U. (2017). Net worth statement, income statement and performance of residential farm business in Maharashtra. Internat. J. Com. \& Bus. Manage, 10(1) : 20-24, DOI: 10.15740/HAS/IJCBM/10.1/20-24. 